\title{
The Reality of Resistance to Change Behaviour at the Department of Correctional Services of South Africa
}

\author{
Mbongeni A. Mdletye \\ Jos Coetzee \\ Wilfred I. Ukpere \\ Department of Industrial Psychology and People Management, Faculty of Management \\ University of Johannesburg, Johannesburg, South Africa \\ E-mail: wiukpere@uj.ac.za, mbongeni@telkomsa.net
}

Doi:10.5901/mjss.2014.v5n3p548

\section{Abstract}

One of the dynamics of transformational change which the study sought to establish within the offender correctional environment was the notion of resistance to change, which forms part of the human dimension of transformational change. This paper presents empirical evidence gathered from the Correctional Centres of the South African Department of Correctional Services in the Province of KwaZulu-Natal on resistance-to-change behavior displayed by the employees of Correctional Services, namely Correctional Officials regarding the fundamental culture change from the punishment-oriented philosophy to the rehabilitation-driven philosophy in terms of the treatment of sentenced offenders (herein referred to as DCS change). Inadequate empirical evidence on the significant role that the human elements and dynamics play in the success or failure of transformational change efforts has motivated the authors to embark on an empirical study which sought to establish whether the paradigm shift from the punitive approach to the rehabilitative approach within the offender correctional environment in South Africa was characterised by the resistance-to-change behavior on the part of correctional officials. The study was significant, particularly if one considers the fact that organisational change scholars (though there are still few who have researched on the subject) have put forward an argument that the high failure rate in the implementation of transformational change interventions is attributed to the neglect of the human factor during the planning and implementation phases of the transformational change management process. Change and transformation strategists, change and transformation implementers, change and transformation agents, change and transformation recipients, organisation development practitioners, and managers in general in both the public and private sector globally and in South Africa in particular will benefit from the study, particular if one considers the fact that transformational change interventions are currently being implemented across the South African public service as part of the government's agenda of reconstructing and developing the South African society. An extensive literature study on resistance to change was undertaken as part of contextualising the resistance-to-change behavior within the Department of Correctional Services and South Africa in general. The literature study was followed by the empirical study which focused on gathering data from correctional officials through utilising a survey questionnaire. The empirical findings revealed that there were indeed elements of resistance-to-change behavior on the part of correctional officials insofar as the DCS change was concerned.

Keywords: Change, organisational change, transformation, organisational transformation, transformational change, change management, perceptions, emotional reactions, experiences, resistance.

\section{Introduction and Background}

People's response to change is one of the elements and dynamics of transformational change which managers must address if success in change implementation is to be achieved. According to Ursiny \& Kay (2007), people respond differently to change. As Sloyan (2009) puts it that understanding employees' responses to transformational change initiatives becomes necessary for purposes of ensuring success in the implementation of transformational change efforts. Organisations currently face changes of unprecedented magnitudes and yet, very little is known about people's' different responses to organisational change as a result of the different effects that organisational change efforts have on people (Briner \& Kiefer, 2005). The response to change is influenced by how the change effort being implemented is perceived and experienced by people individually and collectively. People's different perceptions and experiences of change lead to different responses to change. It is for this reason that Van Tonder (2004a) points out that it is at the level of the individual employee that individual responses to organisational change are formed, based on individual employee's 
perception of change, as well as experience of change (past experiences of change as well). The individual responses (individual support for, or resistance to, change) to organisational change translate into group responses (group support for, or resistance to, change) because of group dynamics and eventually into collective action (i.e. group support for or group resistance to change. People's response to change is viewed from two perspectives, namely people's reaction to change and people's resistance to change.

\subsection{Reaction to change}

Some studies on organisational change suggest that employees' reactions to organisational change are influenced by employees' individual dispositions (Oreg, 2003). People react differently to change due to differences in their perception and experience of change which are attributed to the influence of various personal, demographic, and organisational or contextual factors (Martin, Jones \& Callan, 2006), which signify the diversity of employees. The foregoing points to personal and organisational dynamics that underlie people's different perceptions and experiences of the same change effort and ultimately people's different responses to the change effort (Chreim, 2006). This further implies that because people perceive change efforts differently as a result of the influence of the different factors, their different perceptions lead them to reacting differently to change events, and subsequently experience change initiatives differently (Blanchard, 2005). Organisational change is reacted to and experienced emotionally by employees; hence it evokes strong emotions which represent positive and negative affect. If the experiences are positive, employees will react positively to organisational change efforts. Consequently, they will support the change. But if people's experiences are negative, they will react negatively towards organisational change interventions (Vakola \& Nikola, 2005; Chreim, 2006). Hence they will put up a strong resistance to the change. Therefore, people's reactions to an organisational change effort are shaped by their perceptions and experiences of such an organisational change effort (Chreim, 2006).

\subsection{Resistance to change}

Organisational change efforts fail because of strong resistance to change brought about by employees' negative perceptions of change. Perceptions have a significant and profound role and influence in any change process, particularly when it comes to creating resistance to change. It is for this reason that resistance to change is highlighted as a barrier to the effective and successful implementation of organisational change interventions (Prosci, 2003; Van Tonder, 2004b; Kreitner \& Kinicke, 2004; Coetzee \& Stanz, 2007). It is for the same reason that there are still calls for the expansion of the knowledge base on change and organisational change phenomena so as to include knowledge on the role that human resistance to change plays in the failure of organisational change interventions (Longenecker \& Fink, 2001; Plowman, Beck, Kulkarni, Solansky \& Travis, 2007; Van Tonder, 2004b, 2006, 2008, 2009). Furthermore, people's reactions to organisational change are also influenced, in addition to perceptions and experiences (current and past change experiences) by the way in which organisational change efforts are implemented. And this leads to variance in people's reactions to organisational change (Bareil, Savoie \& Meunier, 2007). When employees perceive the implementation of organisational change as being handled fairly, their reactions to organisational change become more positive. Similarly, when organisational change is perceived to be unfairly initiated and implemented, employees' reactions become more negative (Caldwell, Herold \& Fedor, 2004). Employees' reactions to organisational change are shaped by employees' perceptions of change. These perceptions are influenced by the availability or non-availability of information about the change effort to the employees, as well as being comfortable with or fearful of change (moving from the known to the unknown) (Vithessonthi, 2007). Based on the foregoing, Carr, Hand and Trahant (2006) and Agboola and Salawu (2011) emphasise that resistance to change can be construed as an effort to maintain the status quo.

Tanner (2011) regards resistance to change as an organisational change reality that change implementers must deal with if organisational change efforts are to bear the desired results in line with the change objectives. If resistanceto-change behaviour is not dealt with empathetically and decisively, it can bring a transformational change initiative with good intentions to its knees. Bregman (2009), Haberman (2010), Ford and Ford (2010), and Phoenix (2011) confirm that resistance to change can lead to the downfall of organisational change initiatives. Rodda (2007), conducting an empirical study on the examination of employee reactions to organisational change, concluded that the understanding of the psychological and behavioural foundations of employees' reactions to organisational change is critical for managers who want to manage and support employees who are affected by the change. 


\subsection{Problem statement}

Despite the fact that there is an acknowledgement that resistance to change contributes to the failure of organisational change initiatives (Johnston, 2008; Bregman, 2009; Ford \& Ford, 2010; Haberman, 2010; Harvey, 2011), the current literature on organisational change is not sufficient in this area. It is an established empirical fact that people's negative perceptions and experiences of change bring about negative reactions, which in turn lead to resistance to change (Macri, Tagliaventi \& Bertolotti, 2002; Van Tonder, 2004a). Given this, it is therefore significant to note that resistance to change impacts negatively on change implementation processes, thereby leading to the collapse and failure of many organisational change initiatives (Waddell \& Sohal, 1998; Coetzee \& Stanz, 2007). According to Thomas and Hardy (2011), Smollan (2011 \& 2012), and Hendrickson and Gray (2012), resistance to change is regarded as one of the biggest barriers to the successful implementation of organisational change initiatives.

\subsection{Objectives}

The objectives of this paper are the following:

- To highlight that resistance to change is an organisational change risk which serves as a major obstacle to the effective and efficient implementation of transformational change initiatives and that if not dealt with empathetically and decisively, resistance to change can lead to the collapse of transformational change efforts and as such, it is behind the high failure rate in change implementation;

- To underline the relationship between people's negative perceptions and experiences of change, their negative emotional reactions to change, and their resistance to change as part of accentuating the significant role that the human element plays in determining the success or failure of organisational change initiatives;

- To establish and highlight the negative impact that the resistance-to-change behaviour has on the status of (that is, progress with) transformational change in general across organisations and within the Department of Correctional Services of South Africa in particular;

- To emphasise the importance of managers in establishing, understanding and addressing people's negative perceptions and experiences during the transformational change implementation process as these easily lead to resistance to change if and when not addressed. This requires decisive managerial intervention and action in order to ensure that people as individuals are engaged in a process of personal transformation with a view to wiping off their negative perceptions and experiences which negatively influence progress with change implementation through negative emotional reactions that intensify resistance to change. This will assist in terms of ensuring that the resistance-to-change behaviour is addressed such that its impact on the change implementation process is minimised and contained.

\subsection{Significance and contributions of the study}

The findings of the study will be of great benefit to managers in both public and private sector organisations in South Africa and globally, as the findings will expand the existing knowledge base on resistance to change through adding more empirical evidence. The treatise will certainly benefit change implementers, change recipients, change agents, and organisation development practitioners by enhancing their knowledge and skills on transformational change management, particularly when it comes to the notion of resistance to change and how to deal with it. The paper will be of great interest and value to managers within the Department of Correctional Services of South Africa who are charged with the responsibility of implementing, institutionalising, and sustaining the fundamental culture change from the punishment-oriented philosophy to the rehabilitation-focused philosophy in terms of the treatment of offenders. The value that this article would add to organisational change literature would be its emphasis on the significance of the human dimension of transformational change, particularly the notion of resistance to change which is regarded as a barrier to the effective and efficient implementation of transformational change efforts. The paper has also highlighted the importance of managerial intervention in mitigating the impact of resistance to change on the transformational change process.

\section{Literature Study on Resistance to Change}

Van Tonder (2004b) and Eriksson (2004) explain that all change, of whatever nature, evokes strong, varying emotional responses from most people, which are informed by people's different perceptions and experiences of change. People's 
response to change is underpinned by the reaction to change (positive or negative reaction) and the resistance to change. It is the negative reaction that builds up to opposition to change and ultimately to resistance to change. Organisations, the world over, undergo transformational changes of unprecedented magnitudes as a result of the desire to remain competitive in the intensely competitive and globalised operational environment. And yet, very little is done by managers to understand and address the dynamics of people's reactions to change and the consequence of these reactions, which is the support for or opposition to change and the effect of these on the change implementation process in terms of serving as a facilitator or barrier to the effective and efficient implementation of transformational change efforts.

\subsection{Reaction to change}

According to Van Tonder (2004c), the reaction to change is generally defined as a response to a stimulus and within the context of organisational change, the reaction to change denotes a response to a change initiative, which may be followed by resistance. Organisational change is experienced emotionally by employees and as such, it evokes varying reactions that are underpinned by emotions. Reactions are sparked off by the perception of an insecure future, the perception of inadequate working conditions, and the perception of inadequate treatment by the organisation (Kiefer, 2005).

Jick (1993) provides a useful framework for explaining people's reactions to change, which stipulates that the individual's reaction to change is shaped by the individual's perception of the change initiative and how it is being implemented. If the individual perceives the change as a risk, the reaction to change will be characterised by reactions such as shock (as a result of perceived threat or denial) or defensive retreat (due to anger).

Perceptions are influenced by the availability or non-availability of information about the change effort, as well as being comfortable with or fearful of the change (moving from the known to the unknown) (Vithessonthi, 2007). Given the above, one may argue that negative perceptions of change may be aggravated by the lack of information about the change and the fear to move from the known to the unknown. These contribute to the development of negative emotional reactions to the change, which ultimately translate into resistance to change. The reaction to organisational change efforts is influenced by how a particular organisational change intervention has touched people's work and personal lives. It is this effect on personal and work lives that determines whether an organisational change initiative will be perceived as justified or not. If it is perceived as justified, acceptance is more likely. And this is influenced by people's positive perception of organisational support (Self, Armenakis \& Schraeder, 2007). This implies that the higher organisational support is perceived by people, the more likely that they will perceive the organisational change effort as more justified. But if the change is perceived as unjustified, people will react negatively towards it.

The above argument points to a strong link between people's perception of organisational support and people's reaction to organisational change. High perception of organisational support leads to positive perceptions of organisational change which, in turn, lead to positive reactions to change. Low perception of organisational support leads to negative perceptions of organisational change which, in turn, lead to negative reactions towards organisational change. Hence the resistance to change. What this suggests is that implementers of change initiatives must continuously and systematically monitor people's perceptions, experiences and reactions during the implementation of any change initiative.

\subsection{Resistance to change}

Resistance to organisational change coupled with people's perceptions and experiences of change as influencers of their emotional reactions to change and ultimately resistance to change is fast becoming a matter of interest to organisational change scholars, change agents, and organisation development practitioners (Van Tonder, 2006). This is based on the fact that resistance to organisational change has long been recognised as a critical factor that influences organisational change efforts in a negative sense (Waddell \& Sohal, 1998; ProSci, 1998). Research indicates that $50 \%$ to $75 \%$ of all major organisational change initiatives fail and that resistance is the least recognised but significsnt contributor to the failure of such change efforts (Waddell \& Sohal, 1998; Coetzee \& Stanz, 2007). Many studies on organisational change have posited that resistance to change is a critical construct that needs to be seriously avoided or addressed whenever change implementation takes place (Van Tonder, 2004b; Kreitner \& Kinicke, 2004) due to the fact that resistance to change impacts negatively on change implementation processes, thereby leading to the collapse and failure of many organisational change initiatives. 
What is resistance to change? According to Coch and French (1948: 521), resistance to change is "a combination of an individual reaction to frustration with strong group-induced forces". Lewin (1951) saw resistance to change as the equilibrium between the forces that support change and those that oppose change. Agocs (1997: 918) defines resistance to change as "the pattern of organisational behaviour that decision makers in organisation employ to actively deny, reject, refuse to implement, repress or even dismantle change proposals and initiative". The foregoing three definitions suggest that resistance to change is negative and as such, it should be avoided, minimised or eliminated. According to Maurer (1997), resistance is the primary reason why changes in organisations fail. The key question, therefore, is: Why do people resist organisational change? Resistance to organisational change comes in two forms, namely systemic and behavioural resistance. Systemic resistance emanates from the lack of relevant knowledge, information, skills, competencies and managerial capacity, while behavioural resistance denotes resistance that originates from perceptions, reactions and assumptions of individual people or groups of people within the organisation (Plant, 1987). It is in recognition of the second form of resistance that Eby, Adam, Russell and Gaby (2000) as well as Vas and Lejeune (2004) consider people's perceptions of change as playing a critical role in the process of organisational change and accordingly, in the creation of resistance to change. According to Coetsee $(1999,2003)$, resistance to change involves a continuum of behaviour which ranges from passive resistance to active resistance through to aggressive resistance.

According to Strebel (1996), managers and employees view organisational change differently. For managers, organisational change points to an opportunity; while for employees, organisational change is viewed as being intrusive and disruptive. When managers implement change initiatives through unilateral decisions, organisational change becomes perceived as being intrusive. It is intrusive because it is implemented without the consent of, or consultation with, employees. For this reason, organisational change becomes perceived as invading employees' personal and organisational space. Faced with this situation, employees, as individuals or groups, engage in resistance to change as a way of protecting their personal and organisational space. Dent and Goldberg (1999) have challenged the notion that employees resist change by contending that employees do not resist change as such, but what employees resist is loss of pay, loss of status, or loss of comfort. The two authors argue that resisting the loss of pay, status or comfort is not the same thing as resisting change. Dent and Goldberg are wrong to suggest that employees do not resist change. Employees resist change because change leads to employees losing their pay, their status or their comfort. This suggests that change impacts negatively on employees such that it affects for the worse their pay, their status or their comfort. It is on the basis of the foregoing that employees resist change, as a way of ensuring that their pay, status or comfort zones are protected. Employees resist change and the loss of pay, the loss of status, and the loss of comfort become factors that influence employees' resistance to change. And as such, employees do not resist these factors per se, but rather resist change that impacts negatively on these factors.

Antonacopoulou and Gabriel (2001) emphasise that resistance to change is an essential part of the change process that involves a process of sense-making with a view to re-establishing and reaffirming valued beliefs, habits and ideas, rather than immediately sacrificing or abandoning them for the unknown ones that were never experienced. For this reason, there is a significant relationship between people's perceptions and their resistance to change.

Several reasons can be advanced for resistance to change. Loss of control, status, routines, traditions, relationships, security, competence, as well as fear of the unknown, failure, lack of support, confidence and trust, inappropriate or poor management styles, low tolerance for change, distorted perceptions of change are cited by Isabella (1990) and Mabin, Forgeson and Green (2001) as some of the reasons behind resistance to change. Mabin et al. (2001) highlight that the threat to people's security, self-interest, established habits and freedom to engage in preferred behaviours are other reasons behind resistance to change. The argument that certain factors influence employees' resistance to change is supported by empirical studies conducted by organizational change scholars such as Hannan and Freeman (1988); Spector (1989) (threat to the employee's status); Morris and Raben (1995) (fear of real or imagined effects and different comprehension or evaluation or judgement of the organisational change situation); and Mabin, Forgeson and Green, 2001 (fear of unknown effects). For this reason, one may emphasise that employees resist change as a reaction to the real or imagined consequences of organisational change. Given the foregoing, one may conclude that people's attitudinal reactions to organisational change are fuelled by feelings of uncertainty, hopelessness, loss of control, fear of losing what one has, and fear of failure (Oreg, 2003; Blanchard, 2005; Oreg, 2006; Fedor, Caldwell \& Herold, 2006).

Bourne and Bourne (2000) highlight other factors that underlie employees' resistance to change, namely lack of communication, lack of will to change, lack of acceptance of change, as well as lack of incentive. An empirical study conducted by Bovey and Hede (2001) points to the fact that irrational ideas (cognitions) and emotion are largely associated with resistance to change. Eriksson (2004) cites four major reasons for people to resist change, namely: 
people are afraid of losing something of value; people often misunderstand the change and its implications; people often tell themselves that the change does not make any sense and as such, it will not work; and people often display a low tolerance for change. According to Van Tonder (2004a), causes of resistance to change are unavoidably mediated by perceptions. Employees create their own understandings, perspectives and interpretations of what is likely to happen to them and their organisation as a result of organisational change through perception. Accordingly, these different understandings, different perspectives, different interpretations, and different experiences of the change influence people's reactions to change and ultimately their resistance to change. For this reason, it becomes important for managers, as change agents, to communicate frequently, continuously and enthusiastically with the employees about the change (Lewis, Schmisseur, Stephens \& Weir, 2006; Ford, Ford \& D'Amelio, 2008).

Given the above-named factors, resistance is therefore the primary reason why organisational change efforts fail. This view is supported by the research conducted by Bregman (2009); Haberman (2010); Ford and Ford (2010); and Agboola and Salawu (2011), which point to the fact that resistance to change is one of the primary reasons why organisational change initiatives do not succeed.

\section{Methodology}

This study utilised a two-pronged research approach, which encompassed a literature study and a quantitative empirical study. The study applied three types of research designs - exploratory design, survey design, and descriptive design.

\subsection{Sample, sampling method and population}

A random, purposive and probability samples of 1000 correctional officials and 500 offenders were utilised, which were drawn from 7593 correctional officials and 13, 520 sentenced offenders, thereby constituting $13.17 \%$ and $8.14 \%$ samples respectively.

\subsection{Research procedure}

The procedure followed in the execution of this empirical study entailed conducting a pilot study; administering the research instruments; and scoring the responses. The empirical data was collected by means of two survey questionnaires, one for correctional officials and the other for offenders. A 5-point Likert type response scale was utilised to measure the resistance-to-change behaviour on the part of correctional officials regarding the DCS transformational change.

\subsection{Statistical analysis}

The statistical analysis was conducted in two phases. Phase 1 focused on descriptive statistics with a view to providing proof that the two questionnaires used as measuring instruments were reliable and valid for the purpose of this study. To determine the adequacy and sphericity of the intercorrelation matrix, the Kaiser-Meyer-Olkin (KMO), measure of sampling adequacy (MSA) and the Bartlett's test of sphericity were conducted. A reliability analysis was also conducted on the measuring instruments with the purpose of calculating a reliability coefficient (Cronbach Alpha). Phase 2 dealt with inferential statistics through the utilisation of Structural Equation Modelling (SEM), which was employed to measure the existence of relationships between variables.

\subsection{Response rate}

The return rate of $71.3 \%$ and the frequency rate of $98.2 \%$ for valid responses were recorded for correctional officials. For the offenders' sample, the return rate of $58.2 \%$ and the frequency rate of 97.6 for valid responses were recorded.

\subsection{Structural integrity of measuring instruments}

The inspection of the individual items on both questionnaires reveals high face validity. Regarding content validity, the contents of the questionnaire was found to be relevant to the research questions dealing with correctional officials' resistant-to-change behavior pertaining to the DCS transformational change. Concerning construct validity, it was concluded, based on results of face and content validity, that the questionnaire utilised in the study measured what it was designed to measure in terms of the resistance-to-change behaviour. 


\subsection{Reliability analysis}

The suitability of data for factor analysis was assessed using the KMO measure of sampling adequacy and the Barlett's test for sphericity (Kaiser, 1970). The results of the assessment of suitability of data for factor analysis revealed that the data sets complied with the requirements of sampling adequacy and sphericity and could thus be subjected to factor analysis as the KMO MSA values for the perception and experience of DCS change variables were .942 and .939 respectively, which were highly significant because they were well above the recommended value of 0.6. (Hair, Anderson, Tatham, \& Black, 2003; Hair, Anderson, Tatham \& Black, 2006; Tabachnick \& Fidell, 2007). The Bartlett's test of sphericity values (that is, Sig. values) should be .05 or smaller. The Bartlett's test values reached statistical significance $(p=0.000)$, thereby supporting the factorability of the correlation matrices.

Regarding reliability statistics from reliability analysis, the statistics for the perception of DCS change variable reflects a Cronbach alpha coefficient of .950 from 32 items for the perception and experience of the DCS change; .854 from 11 items for the perceived nature of the DCS change (type if change); and .893 from 18 items for the perceived impact of the DCS change on the DCS as an organisation from the perspective of correctional officials. The Cronbach alpha coefficients indicate that the measuring instrument has acceptable reliability and consistency in terms of measuring the perception and experience of the DCS change, as well as the resistantce-to-change behaviour that they were designed to measure.

\section{Data Analysis and Discussion of Findings}

\subsection{Descriptive statistics of the resistance to the DCS change process}

Tables 1 and 2 point to an element of resistance-to-change behaviour on the part of correctional officials. Reflected in Table 1 below are percentages that represent correctional officials' responses to questionnaire items which were meant to test correctional officials' willingness to be part of a transformational change initiative.

Table 1.. Frequency Table: Resistance to the DCS Change

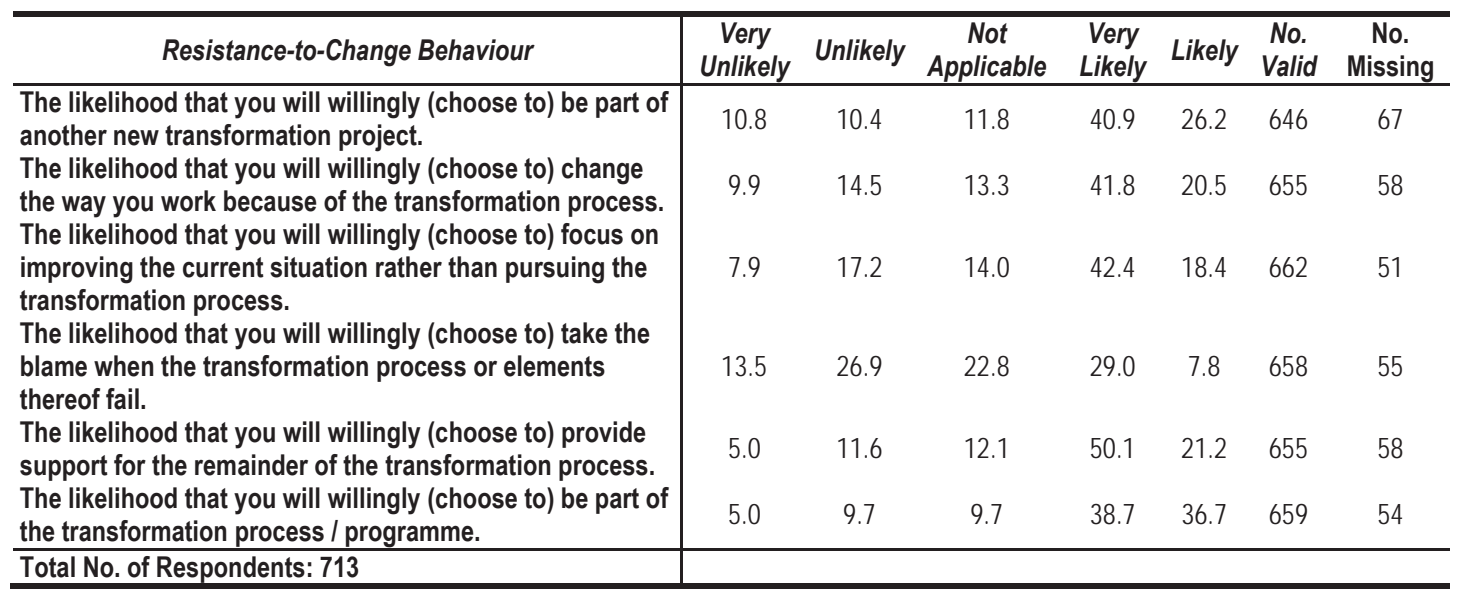

Source: Own Construction

As demonstrated by the frequencies in Table 2, the responses of certain correctional officials point to an element of resistance-to-change behaviour in that they demonstrate their willingness to be part of a transformational change initiative.

Captured in Table 2 below is a frequency table bearing examples of questionnaire items and computed responses that relate to an element of resistance to the DCS transformational change on the part of correctional officials. 
Table 2. Frequency Table: Resistance to the DCS Change

\begin{tabular}{|c|c|c|c|c|}
\hline Statement & Frequency & Percentage & $\begin{array}{c}\text { Valid } \\
\text { Percentage }\end{array}$ & $\begin{array}{l}\text { Cumulative } \\
\text { Percentage }\end{array}$ \\
\hline $\begin{array}{l}\text { If a similar transformation process is to be introduced } \\
\text { tomorrow, I will actively resist the process. }\end{array}$ & 38 & 5.3 & 5.5 & 5.5 \\
\hline $\begin{array}{l}\text { If a similar transformation process is to be introduced } \\
\text { tomorrow, I will firmly denounce participation. }\end{array}$ & 23 & 3.2 & 3.3 & 8.9 \\
\hline $\begin{array}{l}\text { If a similar transformation process is to be introduced } \\
\text { tomorrow, I will maintain a neutral stance. }\end{array}$ & 160 & 22.4 & 23.3 & 32.2 \\
\hline $\begin{array}{l}\text { If a similar transformation process is to be introduced } \\
\text { tomorrow, I will actively support participation. }\end{array}$ & 355 & 49.8 & 51.7 & 83.8 \\
\hline $\begin{array}{l}\text { If a similar transformation process is to be introduced } \\
\text { tomorrow, I will volunteer to lead / facilitate the process. }\end{array}$ & 111 & 15.6 & 16.2 & 100.0 \\
\hline Valid & 687 & 96.4 & 100.0 & \\
\hline Missing & 26 & 3.6 & & \\
\hline Total & 713 & 100.0 & & \\
\hline
\end{tabular}

Source: Own Construction

The line and column charts displayed below indicate the level of resistance-to-change behaviour captured from the correctional officials' responses to the five questionnaire items which relate to resistance to the DCS change.

Figure 1.Frequency Distribution of Resistance to Change

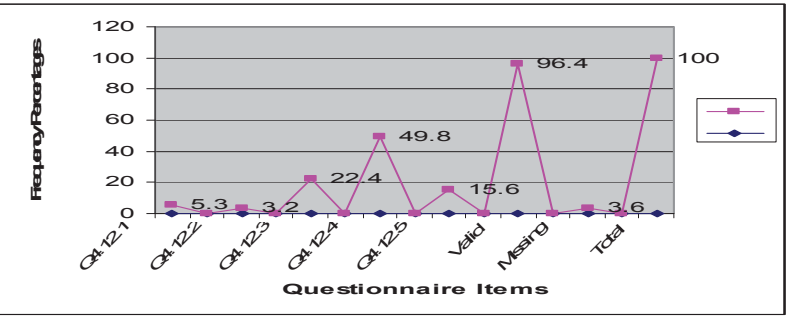

Source: Own Construction

Figure 2. Frequency Distribution of Resistance-to-Change Behaviour

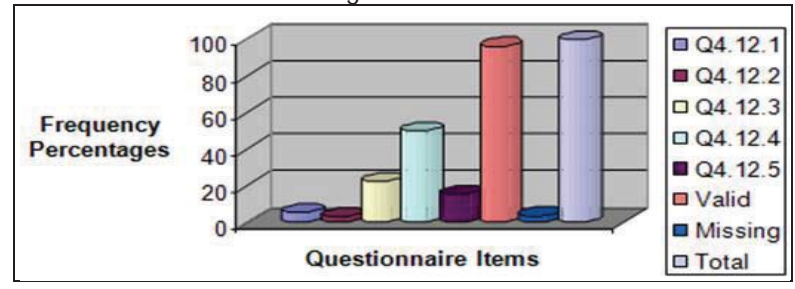

\section{Source: Own Construction}

As can be seen from Figure 1 and Figure 2, the distribution of frequency percentages in terms of correctional officials' responses to the five questionnaire items relating to resistance to the DCS change shows an element of resistance-tochange behaviour. Items 4.12.1, 4.12.2, and 4.12.3 point to this resistance-to-change behaviour. However, what is also of significance to note is that item 4.12 .4 indicates that there is a high percentage of correctional officials who exhibit a support-for-change behaviour. Item 4.12 .5 also points to support for change. This trend was expected, given the fact that the literature review undertaken revealed that whenever transformational change initiatives are implemented, employees are always divided into two groups - those who support change and those who resist change.

\subsection{Response to DCS transformational change}

The response to the DCS transformational change came out in two forms, namely the emotional reactions and the resistance-to-change behaviour, which are described below. 


\subsubsection{Reaction to DCS transformational change}

Zerbe, Hartel and Ashkanasy (2010) point out that organisational events such as transformational change do affect employees' emotions and actions which, in turn, affect organisational events, positively or negatively. Correctional officials emotionally reacted positively and negatively to their experiences of the DCS transformational change. This empirical finding vindicates earlier findings by Van Tonder (2004b), Vakola and Nikola (2005) and Chreim (2006) that organisational changes evoke different emotional reactions on the part of people, which can be either positive or negative.

\subsubsection{Resistance to DCS transformational change behaviour}

Despite the fact that there is an acknowledgement that resistance to change contributes to the failure of organisational change initiatives (Johnston, 2008; Bregman, 2009; Ford \& Ford, 2010; Haberman, 2010; Harvey, 2011), the current literature on organisational change is not sufficient in this area. It is an established empirical fact that employees' negative perceptions of change bring about employees' negative reactions, which in turn lead to employees' resistance to change (Macri, Tagliaventi \& Bertolotti, 2002; Van Tonder, 2004a). According to Thomas and Hardy (2011), Smollan (2011 \& 2012), and Hendrickson and Gray (2012), resistance to change is regarded as one of the biggest barriers to the successful implementation of organisational change initiatives.

Considering the negative impact of resistance-to-change behaviour on the change implementation processes, it is important to note that the study on transformational change in the Department of Correctional Services revealed an element of resistance-to-change behaviour. Responses of 5.5\%, 3.3\% and $23.3 \%$ indicated that correctional officials would actively resist a similar change effort, firmly denounce a similar change effort, and maintain a neutral stance respectively if it were to be introduced in future. This kind of resistance behaviour is quite worrying, given the consequences of resistance to change highlighted above. For Wignaraja (2006), public service organisations are often perceived as resistant to change and as such, it is worrying that correctional officials, as employees of a public service organisation in South Africa (namely the Department of Correctional Services), have displayed a resistance-to-change behaviour towards the DCS transformational change. The admission by certain correctional officials that if faced with another transformational change effort, they would resist, denounce, or adopt a neutral stance vindicates an assertion by Carr, Hand and Trahant (2006) and Agboola and Salawu (2011) that resistance to change is nothing else but the effort to maintain the status quo. The act of disengagement through the maintenance of a neutral stance points to low psychological ownership of organisational processes (Lorenzi \& Riley, 2000) and to psychological withdrawal from any transformational change within Correctional services (Tanner, 2011). It is on the basis of this that Tanner $(2009,2011)$ regards resistance to change as an organisational change reality that change implementers must deal with if organisational change efforts are to bear the desired results in line with the change objectives. If resistance-to-change behaviour is not dealt with empathetically and decisively, it can bring a transformational change initiative with good intentions to its knees. Bregman (2009), Haberman (2010), Ford and Ford (2010), and Phoenix (2011) confirm that resistance to change can lead to the downfall of organisational change initiatives.

\subsection{Summary and implication of findings}

Based on the above-mentioned empirical findings, the following conclusions are made:

- Transformational change involves moving from the known to the unknown and as such, it is natural and normal for people to experience fear and anxiety, hence resistance to change becomes a natural, normal and inevitable phenomenon;

- Resistance to change is not caused by a single factor, but by a multiplicity of factors and as such, it becomes critical for managers to diagnose, identify and address the causes or sources of resistance to change, which can be person-based and organisation-based;

- For managers to be able to deal decisively with resistance to change, they must also determine the nature of resistance to change. Is resistance confronting the organisation a passive, active one or aggressive one? The findings of the study suggests that the resistance-to-change behaviour on the part of correctional officials is characterised by passive and active resistance;

- Factors that cause resistance to change, such as the fear of the unknown, loss of control, loss of status, lack of confidence and trust (in the management for example) make it not easy to deal with resistance to change 
decisively;

- The fact that factors which bring about resistance to change are unavoidably mediated by perceptions makes addressing resistance to change a complicated and complex management issue; and

- Negative attitudes and behaviours which foster resistance to change develop whenever people believe that they are not treated fairly by managers. On the other hand, when people believe that the treatment meted out to them by management is a fair one, they develop positive attitudes and behaviours which facilitate effective and efficient change implementation through lessened resistance to change.

In the light of the above finding summary in respect of resistance-to-change behaviour, the following implications are worth noting:

- Resistance to change is a critical construct that needs to be seriously avoided or addressed whenever change implementation takes place (Van Tonder, 2004b; Kreitner \& Kinicke, 2004). Given what Van Tonder (2004a) suggests that causes of resistance to change are mediated by perceptions, it is important to note that in order to avoid resistance to change, employees' negative perceptions, which lead to negative reactions and which in turn culminate into resistance to change, need to be addressed. And they can only be addressed if managers begin to take interest in the role that employee perceptions play in facilitating or sabotaging organisational change interventions.

- Resistance-to-change behaviour does not augur well for the effective implementation of transformational change in that it interferes with the change process by hindering progress with change implementation;

- Based on the fact that resistance to change stifles and hinders change implementation progress, it means that transformational change efforts can fail due to resistance-to-change behaviour; and

- Resistance-to-change behaviour is influenced by people's negative perceptions and experiences of transformational change.

\section{Recommendations}

\subsection{Recommendations for organizations in general}

The following recommendations are made:

- Managers should create and maintain a proper organisational culture and organisational identity by creating proper attitudes and behaviours in the workplace before, during and after change implementation;

- Managers should build an attitude of acceptance to change among organisational members through articulating and explaining the vision for change to all organisational members;

- Managers should develop abilities necessary to implement transformational changes effectively and successfully by gaining a broader understanding and knowledge of the elements and dynamics of transformational change dealt with in this study, particularly when it comes to identifying and dealing with resistance-to-change behaviour. As Tanner (2010) puts it, managers, who are implementers of change efforts, must develop the ability to both adapt to change quickly and manage it effectively;

- For managers to be able to achieve this, they need competencies (knowledge, skills, attitudes) which include, amongst other, understanding how employees perceive and experience transformational change; how employees react to transformational change; how employees develop resistance towards transformational change; and how resistance-to-change behaviour hinders effective and efficient implementation of transformational change efforts; and

- Managers need to gain a deeper understanding, through capacity building programmes on change and transformation management, of how negative perceptions and experiences of change influence people's emotional reactions in a negative sense and how negative emotional reactions impact negatively on the change process through developing into opposition to change and ultimately culminating into resistance to change.

\subsection{Recommendations for the South African Department of Correctional Services}

For the Department of Correctional Services in South Africa, the recommendations outlined below are worth noting.

- The change strategists and change implementers must conduct a comprehensive assessment of the DCS 
organisational readiness for the DCS change. Although this is belated, it will assist the managers in terms of checking whether the DCS organisational culture does promote the implementation of the DCS change or not. This assessment should be conducted in all 262 correctional centres of the Department of Correctional Services in South Africa in order to establish whether the centres were made ready for the implementation of the change in terms of the organisational culture and individual change;

- Correctional officials should be assisted with attitude change if any change for the better insofar as the treatment of offenders is concerned, is to be realised. Bhengu Baloyi (2012) supports this assertion when arguing that attitude (internal reality) change and outward behaviour (external reality) change are inextricably linked. Change in attitude leads to change in outward behaviour. Change capacity building at individual correctional official level would ensure that correctional officials are trained and developed to embrace not only the DCS change, but also the culture that is being entrenched in line with the implementation and institutionalisation of the philosophy of offender rehabilitation as per the objectives of the DCS transformational change;

- The change strategists should develop a change management capacity-building programme aimed at taking correctional officials at managerial and non-managerial levels on a journey of personal change with a view to changing their mindsets, behaviours and attitudes. This is necessary in view of the finding that the Department has not made any substantial progress with regard to the treatment of offenders due to the attitude of correctional officials towards offenders, as well as the finding that relates to the existence of resistance-tochange behaviour;

- The change implementers in the Department of Correctional Services should deal with the negative experiences of the DCS change on the part of correctional officials. These negative experiences, reflected in terms of correctional officials' emotional reactions to the DCS change, are a cause for concern as they can derail the DCS change implementation if they are not attended to timeously and decisively. They may impact negatively on correctional officials' association with, and commitment to, the Department of Correctional Services as an organisation. This may lead to the intensification of both behavioural and systemic resistance to the DCS change;

- Managers should revamp and intensify their communication strategy around the transformational change to rehabilitation. This will assist in terms of reducing or eliminating organisational change cynicism;

- Correctional Services managers (in the name of change strategists and change implementers) must become more supportive to non-managerial correctional officials who are unfortunately placed in the position of being both change implementers and change recipients; and

- Executive managers in the Department must focus more on recognising and rewarding correctional officials who are involved in creating a conducive organisational climate for change. Promotion through the application of a promotion policy can assist in making correctional officials to accept the transformational change to rehabilitation whole-heartedly.

\section{Conclusion}

The results of the empirical study have revealed the existence of resistance-to-change behaviour in the implementation of the DCS transformational change from the punishment-oriented paradigm to the rehabilitation-driven paradigm insofar as the treatment of sentenced offenders is concerned. The existence of the resistance-to-change behaviour points to the fact that any implementation of organizational change effort is always accompanied by resistance and as such, managers need to acknowledge and accept that resistance to change is a change management issue that should be seriously, empathetically and decisively addressed if transformational change efforts are to bear the desired results in terms of the set change objectives. Furthermore, it can be argued that resistance-to-change behaviour, being an integral part of organisational life insofar as change implementation is concerned, is a threat to the effective and efficient implementation of transformational change interventions and as such, managers who discount and negate any resistance-to-change behaviour during change implementation process do so at the peril of their organisations. They must know that if they ignore resistance-to-change behaviour, they will produce dismal change implementation results.

\section{References}

Agboola, A.A. \& Salawu, R.O. (2011). Managing deviant behaviour and resistance to change. International Journal of Business and 
Management. 6(1), 235-242.

Agocs, C. (1997). Institutionalised resistance to organisational change: Denial, inaction and repression. Journal of Business Ethics, 16, 917-931.

Antonacopoulou, E.P. \& Gabriel, Y. (2001). Emotion, learning and organizational change: Towards an integration of psychoanalytic and other perspectives. Journal of Organizational Change Management, 14(5), 435-451.

Bareil, C., Savoie, A., \& Meunier, S. (2007). Patterns of discomfort with organisational change. Journal of Change Management, 7(1), 13.

Bhengu Baloyi, L.N. (2012). Change beyond form. Durban: The African Midwife Institute.

Blanchard, K. (2005). Leadership and change: From knowing yourself to handling change. Management Today, 21(5), 16-21.

Bourne, M. \& Bourne, P. (2002). Change management in a week. London: Hodder \& Stoughton.

Bovey, W.H. \& Hede, A. (2001). Resistance to organisational change: The role of cognitive and affective processes. Leadership and Organization Development Journal, 22, 372-382.

Bregman, P. (2009). How to counter resistance to change. Harvard Business Press. Retrieved from: http://www.google.com on 08 August 2012.

Brinier, R.B. \& Kiefer, T. (2005). Research into the Experience of Emotion at Work: Definitely Older, But are we any Wiser? In N.M. Ashkanasy, C. Hartel, \& W. Zerbe (Eds.), The effect of Affect in Organizational Settings - Research on Emotion in Organizations, Vol. 1, Oxford, UK: Elsevier/JAI Press.

Caldwell, S.D., Herold, D.M., \& Fedor, D.B. (2004). Toward an understanding of the relationships among organizational change, individual differences, and changes in person-environment fit: A cross-level study. Journal of Applied Psychology, 89(5), 868-882.

Carr, D.K., Hand, H.J. \& Trahant, W.J. (2006). Managing the change process: A field book for change consultants, team leaders and reengineering managers. New York: McGraw-Hill.

Chreim, S. (2006). Postscript to change: Survivors' retrospective views of organisational changes. Personnel Review, 35(3), 315.

Coch, L. \& French, J.R.P. Jr. (1948). Overcoming resistance to change. Human Relations, 1, 512-532.

Coetzee, C.J.H. \& Stanz, K.J. (2007). "Barriers-to-change" in a governmental service delivery type organisation. SA Journal of Industrial Psychology, 33 (2), 76-82

Coetsee, L. (1999). From resistance to commitment. Public Administration Quarterly.

Coetsee, L. (2003). From resistance to commitment. Public Administration Quarterly, 23, 204-223.

Dent, E.B. \& Goldberg, S.G. (1999). Challenging resistance to change. Journal of Applied Behavioural Science, 35, 25-41.

Eby, L.T., Adam, D.M., Russell, J.E.A., \& Gaby, S.H. (2000). Perceptions of organizational readiness for change: Factors related to employees' reactions to the implementation of team-based selling. Human Relations, 53(3), 419-442.

Eriksson, B. (2004). 'The effects of change programs on employees' emotions' Personnel Review, Vol. 33(1), 110-126.

Ford, J.D. \& Ford, L.W. (2010). Stop blaming resistance to change and start using it. Organizational Dynamics, 39(1), 24-36.

Ford, J.D., Ford, L.W., \& D'Amelio, A. (2008). Resistance to change: The rest of the story. Academy of Management. The Academy of Management Review, 33(2), 362

French, W.L. \& Bell, C.H. (1995). Organisational Development. Behavioural Science Intervention for organisation improvement. Englewood Cliffer: Prentice-Hall, Inc.

Haberman, M. (2010). Resistance to change: Does it doom us to failure? Retrieved from: http://www.google.com on 23 May 2011.

Hair, J. F., Anderson, R. E., Tatham, R.L. \& Black, W. C. (2003). Multivariate Data Analysis (5th ed.), India: Pearson Education.

Hair, J.F., Anderson, R.E., Tatham, R.L. \& Black, W.C. (2006). Multivariate data analysis. (6 th ed.). Upper Saddle River, NJ: Prentice-Hall.

Hannan, M.T. \& Freeman, J. (1988). Structural Inertia and organizational change. In K. Cameron, R. Sutton, and D. Whetten (eds.). Readings in organisational change, $75-94$. Cambridge, MA: Ballinger.

Harvey, S. (2011). Ways that people resist organisational change. Retrieved from: http://www.ehow.com/info_8313436_ways-people-resistorganisational-change on 28 May 2011.

Hendrickson, S. \& Gray, E.J. (2012). Legitimizing resistance to organizational change: A social work social justice perspective. International Journal of Humanities and Social Science, 2 (5), 50-59.

Isabella, L.A. (1990) Evolving interpretations as a change unfolds: how managers construe key organizational events, Academy of Management Journal, 33(1), 7-41.

Jick, T. (1993). Managing change: Concepts and cases. Burr Ridge: Irwin.

Johnston, G. (2008). Change management - Solutions to the high failure rate. Change scares people. Retrieved from: http://www.google.com on 09 May 2012.

Kaiser, H.F. (1970). A second generation Little Jiffy. Psychometrika, 35, 401-415.

Kent, R.H. (2003). Conquering 2003 and beyond. The Mansis Development Corporation. Retrieved from: http://www.google.com on 12 June 2011.

Kiefer, T. (2005). Feeling bad: antecedents and consequences of negative emotions in ongoing change. Journal of Organisational Behaviour, 26(8), 875

Kinsey, C. (2000). The biggest mistakes in managing change. Innovative Leader. 9(12)

Kreitner, R. \& Kinicke, A. (2004). Organizational Behaviour. (6 ${ }^{\text {th }}$ Edition) McGraw Hill, Boston.

Lewin, K. (1951). Field theory in social science. New York: Harper Row.

Lewis, L.K., Schmisseur, A.M., Stephens, K.K., \& Weir, K.E. (2006). Advice on communicating during organizational change. Journal of Business Communication, 43, 113-137

Longenecker, C.O., \& Fink, L.S. (2001). Improving management and performance in rapidly changing organizations. Journal of Management Development, 20(1), 7-18

Mabin, J.V., Forgeson, S., \& Green, L. (2001). Harnessing resistance: Using the theory of constraints to assist change management. Journal of European Industrial Training, 25, 168-191.

Macri, D.M., Tagliaventi, M.R., \& Bertolotti, F. (2002). A grounded theory for resistance to change in a small organization. Journal of Organizational Change Management, 15(3), 292-310.

Martin, A. J., Jones, E. S. \& Callan, V. J. 2006. Status and role differences in adjustment during organizational change. Journal of Managerial 
Psychology, 21 (2): 145-162.

Maurer, R. (1997). Transforming resistance. HR Focus, 74(10), 9

Morris, K. \& Raben, C. (1995). The fundamentals of change management. In D. Nadler, R. Shaw, A. Walton, \& Associates (eds.). Discontinuing change: Leading organisational transformation, 47-65. San Francisco, CA: Jossey-Bass.

Oreg, S. (2003). Resistance to change: developing an individual difference measure. Journal of Applied Psychology, 88(4), 680-693.

Oreg, S. (2006). Personality, context and resistance to organizational change. European Journal of Work and Organizational Psychology, 15(1), 73-101.

Phoenix. (2011). Why personal and organizational changes are still not? Retrieved from: http://www.google.com on 23 August 2011.

Plant, R. (1987). Managing change and making it stick. Aldershot: Gower Publishing Co.

Plowman, D.A., Beck, T.E., Kulkarni, M., Solansky, S.T., \& Travis, D.V. (2007). Radical change accidentally: The emergence and amplification of small change, Academy of Management Journal, 50(3), 515-543.

ProSci (1998). Best practices in managing change. Retrieved from the World Wide Web, http://www.prosci.com on 06 February 2010.

ProSci (2003). Change management. http://prosci.com/change-management.htm

Rodda, J. (2007). A multilevel examination of employee reactions to organizational change. PhD Dissertation. DePaul University, Chicago.

Self, D.R., Armenakis, A.A., \& Schraeder, M. (2007). Organisational change content, process, and context: A simultaneous analysis of employee reactions. Journal of Change Management, 7 (2), 211.

Sloyan, R.M. (2009). Trust, sensemaking and individual responses to organizational change. Doctoral Dissertation. Benedictine University.

Smollan, R.K. (2011). The multi-dimensional nature of resistance to change. Journal of Management and Organization, 17 (6), 828-849.

Smollan, R.K. (2012). Chapter 6 Emotional Responses to the Injustice of Organizational Change: A Qualitative Study, in Neal M. Ashkanasy, Charmine E.J. Härtel, Wilfred J. Zerbe (ed.) Experiencing and Managing Emotions in the Workplace (Research on Emotion in Organizations, Volume 8), Emerald Group Publishing Limited, 175-202

Spector, B.A. (1989). From bogged down to fired up: Inspiring organizational change. Sloan Management Review, 30, 32-46.

Strebel, P. (1996). Why do employees resist change? Harvard Business Review on Change, 74(3), 86.

Tabachnick, B. \& Fidell, L. (2007). Using multivariate statistics. (5 $5^{\text {th }}$ ed). Boston: Allyn \& Bacon.

Tanner, R. (2009). Organizational change: 8 reasons why people resist change. Business Consulting Solutions LLC. Retrieved from: http://www.google.com on 23 August 2012.

Tanner, R. (2010). Ornaizational change management: Four truths leaders should know about organizational change. Business Consulting Solutions LLC. Retrieved from: http://www.google.com on 23 August 2012.

Tanner, R. (2011). Leading change (step 7) - Consolidate gains and implement more change. Retrieved from: http://www.google.com on 23 August 2012.

Thomas, R. \& Hardy, C. (2011). Reframing resistance to organizational change. Scandinavian Journal of Management, $27,322-331$.

Ursiny, T. \& Kay, B.A. (2007). The top performer' guide to change. Napierville: Sourcebooks, Inc.

Vakola, M. \& Nikolaou, I. (2005). Attitudes towards organisational change. What is the role of employees' stress and commitment? Employee Relations, 27 (2), 160-174.

Van Tonder, C.L. (2004a). Organisational change: Theory and practice. Pretoria: Van Schaik.

Van Tonder, C.L. (2004b). Organisational Development - Purposefully engaging change, Part I. Management Today, 20(10)/Yearbook 2005, 51$53,57$.

Van Tonder, C.L. (2004c). The march of time and the "evolution" of change. SA Journal of Industrial Psychology, 30 (3), $41-52$.

Van Tonder, C.L. (2006). Change risk and ignorance: Attempting to cross chasms in small steps. SA Journal of Human Resource Management, 4 (3), 1-11.

Van Tonder, C.L. (2008). Stacking the dominoes... courting catastrophe at the "edge-of-chaos". Proceedings of the 9th IFSAM World Management Conference, Shanghai, People's Republic of China, 26-28 July.

Van Tonder, C.L. (2009). Organization identity as managerial concern. In N. Delener, L. Fuxman, F. Victor Lu, A. Putnova \& L.E. Rivera-Solis (Eds.), Readings book: Eleventh International Conference of the Global Business and Technology Association(GBATA), 1171-1177.

Vas, A. \& Lejeune, C. (2004). Revisiting resistance to change at the university: An interpretative approach. Working Paper. Center for Research in Change, Innovation and Strategy.

Vithessonthi, C. (2007). Perceptions affecting employee reactions to change: Evidence from privatisation in Thailand. The Journal of American Academy of Business, 12 (1), 248-255.

Waddell, D. \& Sohal, A.S. (1998). Resistance: a Constructive Tool for Change Management. Management Decision, 36 (8), 543-548.

Wignaraja, K. (ed). (2006). Institutional reform and change management: Managing change in public sector organisations. A UNDP Capacity Development Resource Conference. Conference Paper \#5. Bureau for Development Policy. Retrieved from: http://www.google.com on 25 June 2011.

Zerbe, W. J., Härtel, C. E. J., \& Ashkanasy, N. M. (2010). Emotions and Organizational Dynamism. Bingly, UK: Emerald Group/JAl. 